\title{
Decomposing Employment Growth in Selected sub-Saharan African Countries: The Roles of Structural Changes and Demographic Transition
}

\begin{abstract}
Abidemi C. Adegboye ${ }^{1}$ and Clement A. U. Ighodaro $^{2} 3$
The challenge of employment growth in SSA countries goes beyond economic growth prospects to include structural and demographic dimensions. This study examines the relative contributions of structural changes and demographic factors to employment growth for a set of sub-Saharan Africa (SSA) countries using available annual data from 1970 to 2014. A decomposition approach is employed in the study using the Jobs Generation and Growth (JoGGs) method which generates results that show distributive components of employment, productivity and output changes over time in a system whereby the roles of economic structure and demographic changes could be observed. The study shows that the pattern of structural change in SSA countries has led to more low-productivity and vulnerable jobs generation. Rising shares of the traditional services sector in the economy has driven a large segment of employment into informal low-wage jobs. Major consequences of the nature of demographic changes in the SSA region are found to include decline in overall employment rate and large movement of the labour market towards less productive and low-wage employment. Social policies that address population and migration are therefore required to ensure that demographic factors do not further inhibit availability of productive employment in SSA.
\end{abstract}

Keywords: Decomposition, employment rate, output growth, productivity, sectoral shares JEL Classification: J4, J11, J62, O4, O17

DOI: $10.33429 /$ Cjas.11220.6/8

\section{Introduction}

Growth stories for many sub-Saharan African (SSA) countries since the late 1990s have been impressive, with sustained periods of high output growth (African Center for Economic Transformation, 2014; Adegboye, Egharevba, \& Edafe, 2019). These countries are also experiencing rapid expansions in population and other demographic indicators with resultant inflation of the workforce and imposition of further constraints on productive capacities (Fox,

\footnotetext{
${ }^{1}$ Corresponding author: Department of Economics, University of Lagos, Akoka, Yaba, Nigeria.

Email: cornabi@gmail.com

${ }^{2}$ Department of Economics, University of Benin, Benin City, Nigeria.

${ }^{3}$ The study was carried out with the financial support of the African Economic Research Consortium (AERC) PhD thesis research grant
} 
Decomposing Employment Growth in Selected sub-Saharan

African Countries: The Roles of Structural Changes and

Demographic Transition

Adegboye and Ighodaro

Senbet, \& Simbanegavi, 2016). This has rendered the dynamics of the growth-employment relationships in the SSA region highly heterogeneous, with dimensions on distributive employment shares involving demographic compositions and the level of vulnerability of employment. In practice, growth patterns that generate consistent and sustainable employment opportunities are best realised through accompanying transformation of the structure of the economy. This results in shifts in the composition, proportion, and labour shares in basic sectors of the economy, boosts in overall labour productivity over time, and changes in the population structure. This pattern of growth has been entrenched both in theoretical and empirical investigations (Ranis \& Fei, 1961; Khan, 2011; World Bank, 2012; Diao, Harttgen \& McMillan, 2017).

Structural changes embody the "sequential process through which the economic, industrial and institutional structure of an underdeveloped economy is transformed over time" (Todaro \& Smith, 2009). However, the pattern of structural dynamics observed among SSA countries does not appear to align with theoretical models of development given that the manufacturing sector has played an insignificant role in the structural dynamics of many of the economies (Rodrik, 2016; Haraguchi et al., 2019). For instance, the average share of manufacturing in total output was 10.9 percent in 1970 and 10.6 percent in 2014, indicating persistently low levels over the 44-year period. Though structural bottlenecks are pervasive in SSA economies, population and its dynamics present another emphatic consideration in employment issues in the region. The Malthusian position about population growth is that a growing economy may yet experience downward welfare performance. Demographic characteristics have also contributed significantly to the deep segmentation in the region's labour markets. For instance, the conditions of informal employment within the urban sectors in African economies have intensified in recent periods due to the rising inflow of young job seekers (Martins, 2019; Coulibaly,Gandhi \& Mbaye, 2019). Structural and demographic settings within African economies therefore provide a stimulating background for examining labour markets behaviour in the region.

This study aims at decomposing employment growth for a group of sub-Saharan African countries into the effects arising from changes in economic structure and demography. We seek to examine the relative contributions of changes in sectoral shares of output and changes in population demographics on employment since the 1970s. Although previous studies have 
considered these sorts of decomposition (Timmer \& de Vries, 2008; Mcmillan \& Rodrik, 2011; Fuchs \& Weyh, 2014; Kuusk, Staehr, \& Varblane, 2015; Ajakaiye et al., 2016), their focus was on individual countries with data covering brief periods and broad sectors of the economy. In particular, consideration of broad sectors of the economy tends to obscure unique patterns of structural composition of SSA economies. For instance, while the industrial sector in most SSA countries is composed of a high proportion of non-manufacturing activities (mostly extractive activities), larger proportions of the industrial sector comprises manufacturing activities in advanced economies (Haraguchi et al., 2019). Moreover, the services sector is remarkably diverse in terms of employment structure or productivity patterns in many developing countries (Page \& Shimeles, 2015; Adegboye et al., 2019). On this basis, we perform decomposition analysis employing a wide spectrum of 10 sectors within each of the economies in the study. In this manner, the direct roles of structural changes and demographic transition on employment changes are observed.

The rest of the paper is structured as follows: theoretical and empirical literature review are presented in Section 2, while the data and methodology considerations are demonstrated in Section 3. In Section 4, results and discussion are presented, and conclusion and policy recommendations are drawn in Section 5.

\section{Literature Review}

\subsection{Theoretical Literature}

Structural transformation models developed by Lewis (1954), Ranis and Fei (1961), and Harris and Todaro (1970) provide strong analytical foundations for employment and labour market conditions in developing countries with changing economic structure. The Lewis model considers employment as both a cause and consequence of structural transformations in developing economies. The focus of employment in the model is in the modern sector which Lewis believes to be the only sector capable of providing productive employment for developing economies. According to the model, "both the structure and size of labour demand should alter as sectoral transformation shifts production from primary to modern sectors". Also, the model shows that capital accumulation in the modern sector is a basic requirement for producing sustainable employment associated with changes in the structure of an economy. The Harris-Todaro theory suggests that structural dynamics in the economy lead to increases in the probability of being hired in the urban sector. However, structural dynam- 
Decomposing Employment Growth in Selected sub-Saharan

African Countries: The Roles of Structural Changes and

Demographic Transition

Adegboye and Ighodaro

ics that do not favour higher modern sector employment shares and disproportionately large labour force limit the probability of being hired and elasticity of demand for labour are low (Ajakaiye et al., 2016). This is compounded by the rigid (and therefore fixed) wages in the urban sector due to institutional factors. This rigidity makes labour always flock to urban areas, creating more unemployment. Thus, based on this model, employment changes in many SSA economies are largely results of demographic movements and structural factors. The Lewis and Hariss-Todaro models therefore show how the scarcity of relatively high-paying modern sector jobs give rise to dualism and how surplus labour is reflected in aggregate unemployment as well as rising urban informal employment.

Theoretical underpinnings on employment within a system of structural and demographic changes have however been considered with certain concerns. For instance, Campbell (2013) observed that the classic progression of structural change may not be apparent in all economies, thereby giving rise to two uncertainties. First, there are worrying incidences of deindustrialization instead of growth in the manufacturing sector during processes of transformation in many SSA countries (Carmignani \& Mandeville, 2014). Deindustrialisation tends to hamper structural transformations that provide more capital to the modern sector and ensure steady capital investment and employment opportunities in the urban markets. Second, there are doubts about the pattern and the dimension of rapid increases in service sector-based employment which pervades many developing countries. Countries with low indicators of development are witnessing strong growth in the services sector employment (Fields, 2011; Aggarwal, 2018), which is against the theoretical progression of the system of employment during structural transformation. A critical aspect of the dimension of employment growth for developing economies (including SSA countries), which has received only a passing consideration in theory, is the explicit role of the particular structure of demographic changes in the economies. Although Fields (1975) extended the Harris-Todaro model to provide implication of large population on employment in the modern sector, focus on demographic structure of the population in relation to employment is not essentially highlighted.

\subsection{Empirical Literature}

Studies of structural transformation and its implications for economic performance, including employment in Africa are mostly panel data-based, and they are few (see McMillan \& Rodrik, 2011; McMillan \& Harttgen, 2014; Gong, 2015; Diao et al., 2017). In particular, 
McMillan and Harttgen (2014) noted that "Africa has been largely absent from empirical work on structural change". Hence, they set out to document a number of stylized facts on Africa and also investigated the effects of structural change on employment and growth in the region. They found that between 1990 and 1999, structural change was a drag on economywide productivity growth in Africa due to an unusually rising labour force. This has had implications on the number of jobs emanating from the changes in economic structure. In particular, De Michelis, Estevao and Wilson (2013) found that the pattern of employment generated by developing economies experiencing declining productivity is mainly vulnerable and low-wage. In the same vein, Gong (2015) conducted a comprehensive study on the structure of economies in Africa and found evidence of large lapses in intersectoral integration among the economies that led to poor job yields. For the West African sub-region, Haile (2018) showed that the pattern of structural changes has not improved productive employment. Structural factors also affect the nature of labour markets participation in Africa (Bhorat et al., 2016; Campbell, 2013; Osei \& Jedwab, 2016; Diao et al., 2017). For instance, Page and Shimeles (2015) noted that "when African workers find a job, it is likely to be of low quality in terms of wages, benefits, and job security". The African Development Bank (AfDB, 2012) also reported the preponderance of informality and under-employment in African economies. Their study showed that apart from Botswana, Nigeria, and South Africa, less than 20 percent of entrants into the labour force for many SSA countries tend to find wage employment.

Data availability has proved a daunting challenge for estimating structural, productivity or employment changes in SSA. For most periods, data on employment shares and the levels of productivity have been difficult to determine (Herrendorf, Rogerson, \& Valentini 2014). Recent studies have tended to use a combination of data and data sources to enrich the empirical results. For instance, Diao, et al. (2017) used a combination of data from the Groningen Growth and Development Center's Africa Sector Database and the Demographic and Health Surveys to estimate structural changes and employment growth in Africa. The formulated dataset enabled the authors to consider demographic ramifications of employment growth within structural changes in the region.

Studies on the nexus between demographic patterns and employment (including the International Labour Organisation (ILO, 2013) have noted that demographic changes have important 
Decomposing Employment Growth in Selected sub-Saharan

African Countries: The Roles of Structural Changes and

Demographic Transition

Adegboye and Ighodaro

implications for the labour market identities in developing countries. The labour force participation rate is therefore inextricably linked with both demographic trends and the varying characteristics of the population. As Martinez-Fernandez and Weyman (2012) noted, different population groups exhibit different labour market participation characteristics. This is in line with the finding by World Bank (2012), using data for all developing countries, that the employment levels in a country evolves in line with the different stages of their demographic transition. Thus, the studies on demographics-employment relationships have considered many aspects of demographic transition in line with employment changes both for country groups and single country cases.

Lam and Leibbrandt (2014) formulated a model that demonstrated that a simple consideration of population cohorts and employment may not generate enough evidence on the demographic change-employment nexus. They rather found evidence that the growth rate in the working-age population in developing countries had a significant negative effect on youth employment. Thus, it is the rate of growth of entire population segments that has more relevance in terms of testing the effects on employment. Newhouse and Wolff (2014) found that among developing countries a10 percent increase in population leads to a decline in employment rate by 0.7 percentage point. For Africa alone, Newhouse (2020) found that reducing a cohort population by 10 percent sharply increases the share of workers in non-agricultural sectors by 5 percentage points. Fox et al. (2016) showed that the persistently high fertility rates in many SSA countries has resulted in an unchanged employment structure in the region (low productivity, high informality) even when economic growth was impressive. For advanced economies, Boulhol (2009) found that the pattern of population structure significantly affects variations in labour utilisation and productivity, with larger structures limiting productivity.

From one perspective, employment outcomes have been revealed to be both part of the process, as well as the outcome of structural changes and demographic dynamics in an economy (Mcmillan \& Rodrik, 2011; McMillan \& Harttgen 2014; Ajakaiye et al., 2016). Such analyses were mainly based on results from decomposition analysis that present shift-share investigation of how output growth and productivity changes could affect employment yields. Bbaale (2013) employed the Job Generation and Decomposition (JoGGs) system of the Shapely decomposition to observe whether growth was jobless in Uganda. He found that 
the services sector enlargement and rising productivity were the main factors driving employment in Uganda. For Nigeria however, Ajakaiye et al. (2016) employed the same JoGGs technique but found that growth was actually jobless in Nigeria, with labour flowing into the low productivity sectors of the economy. Kabeta and Sidhu (2016) found large contributions of the services sector to both productivity and growth for Ethiopia using decomposition analysis. These results were also in line with sharp productivity declines arising from larger labour force as shown in Adeyinka et al. (2016).

From the literature, there is evidence that more nuanced evaluations of the contributions of sectoral/demographic factors to employment changes over time are obtained using decomposition techniques. A major aspect that these studies did not consider is the role of demographic changes within a decomposition framework for African economies. The previous studies only considered demographic factors as extraneous in the accounting procedure where demographic effects were held constant. Also, given the peculiarity of economies in SSA (with significantly heterogeneous sub-sectors within industry and services sectors), consideration of broad sectors of the economy tends to obscure their unique patterns of structural composition of SSA economies. Hence, this study varies from previous studies by focusing on more specific aspects of economic structures and paying attention to demographics as a direct link to employment characteristics in SSA countries.

\section{Data and Methodology}

\subsection{Data}

The full data necessary for the decomposition is available for 11 SSA countries between 1960 and 2010 obtained from the Groningen Growth and Development Center (GGDC) 10-Sector Database. Ten of the 11 SSA countries are included in this study since the data on Zambia do not have enough disaggregation of sectoral employment distribution. For instance, the employment dataset does not contain data for government employment, which is an important segment of the services sector of most SSA countries (Campbell, 2013; Coulibaly et al., 2019). The ten countries in the study include the five largest economies in SSA with robust population and labour markets (Timmer et al., 2015). The data for 2011 to 2014 are supplemented from the Diao et al. (2017) dataset and the ILO database. The dataset is preferred to other datasets on sectoral value added because it provides a large-scale sectoral disaggregation of both value-added output and employment. For instance, output and employment 
Decomposing Employment Growth in Selected sub-Saharan

African Countries: The Roles of Structural Changes and

Demographic Transition

Adegboye and Ighodaro

in industries are disaggregated into extractive industries and manufacturing, while services are disaggregated into six sub-sectors. Thus, for the decomposition analysis, the economies were each disaggregated into 10 sectors. Other datasets (like the World Bank's WDI) only engage in a 3-sector decomposition of employment.

The data and decomposition were then used to describe patterns of employment growth resulting from structural change and demographics among the SSA countries for the periods between 1970 and 2014, and between 2000 and 2014. The choice of the period is based on the fact that most SSA economies began to take a foothold on development in the 1970s (Rodrik, 2016), while robust datasets are only available till 2014. The reason for the selection of the pairs of years is the consideration that fundamental structural changes occurred in the SSA economies between the 1970s and 2014. Examples are the IMF Structural Adjustment Programme (SAP) of the mid 1980s and series of liberalisations that occurred in the 1990s. In particular, the structure of most of the economies (e.g., Nigeria, Ghana, Ethiopia, Kenya) moved away from large governments and into more private sector-led participation during the period. Hence, significant structural patterns could be observed during the period, with implications for the structure of employment. The decade following year 2000 marked the "golden years" of African economies when rising commodity prices and stronger institutions (emerging democracies in Nigeria, Ghana, Ethiopia, etc) stimulated strong macroeconomic performances (Jayne et al., 2018). For instance, "six of the world's 10 fastest growing countries in the 2000s were in Sub-Saharan Africa: Mauritius at 11.1 percent a year, Nigeria 8.9 percent, Ethiopia 8.4 percent, Chad 7.9 percent, Kenya 7.9 percent, and Rwanda 7.6 percent" (African Center for Economic Transformation [ACET], 2014). It was an ostensibly significant upgrade from the lost decade of 1990-1999 (Acemoglu et al., 2005).

\subsection{The Decomposition Methodology}

The basic framework for the decomposition analysis involves decomposing employment within structural changes (using sectoral demand and productivity gains/losses) and demographic profiles. By tracking demand, productivity, and corresponding employment shares of individual sectors over time, the change in share-weighted productivity can be decomposed into two or more components. In this study, the method of Shapely decompositions technique, which is essentially a simple additive method of decomposition is adopted. In linking changes in employment to changes in total per capita output and sectoral shares, the relative 
role of demographic changes can also be observed. The starting point of employment decomposition is the "fundamental identity" (1) which shows the endogenous relationship among output, employment and productivity (Rifkin (1994):

$$
\text { out put }=\text { employment } \times \text { productivity }
$$

The identity shows that employment and productivity contribute to every unit of output obtained. In per capita terms, output per capita is explained by employment rate and labour productivity, suggesting that rising employment increases output per capita. Adjusting the identity in terms of employment rate will show that employment is inversely related to both productivity and size of labour force (which is due to population). Hence, conceptually, demographic transition that increases the share of the working age population or disproportionately increases sectors that are capital intensive will lead to less employment prospects.

Different methods have been used to operationalize employment decomposition. For instance, Timmer et al. (2015) employed the canonical method which uses base years as reference period, while Havlik (2015) employed the input-output procedure which focuses on capturing the technological intensity of sectors, rather than on the labour input. In general, these methods are similar, especially in outcomes and give the direct positions of productivity (and employment) changes due to structural changes. The "Job Generation and Growth (JoGGs) decomposition tool" from the World Bank (2006) is employed in systematically presenting the Shapely decomposition. Following the Identity in (1), the JoGGs methodology decomposes GDP per capita as:

$$
\frac{Y}{N}=\frac{Y}{E} \times \frac{E}{W} \times \frac{W}{N}
$$

where $Y$ is total output and $N$ is total population, $E$ is the total population in employment and $W$ is total working-age population. These imply that $Y / N$ is the output (value added) per capita, $Y / E$ stands for output per worker or average productivity of labour, $E / W$ is proportion of working age population in employment (or the employment rate), and $W / N$ is proportion of the labour force in total population. (2) can be rewritten as:

$$
y=p \times r \times \omega
$$

This shows that $y$ is value added per capita, $p$ is average productivity, $r$ is employment rate, and $\omega$ is age structure. Growth in output for a given period can then be decomposed into the 
marginal contribution of each of the per capita variables in (3) as:

$$
\frac{\Delta y}{y}=\underline{p} \frac{\Delta y}{y}+\underline{r} \frac{\Delta y}{y}+\underline{\omega} \frac{\Delta y}{y}
$$

where $\underline{p} \frac{\Delta y}{y}, \underline{r} \frac{\Delta y}{y}$, and $\underline{\omega} \frac{\Delta y}{y}$ each represents the marginal contribution of $p, r$ and $\omega$, respectively, to output growth. Note that $\underline{p}, \underline{r}$, and $\underline{\omega}$ are the proportion of growth attributable to productivity, employment and labour force, respectively. Given that the relative shares are relatively constant over given periods of time, the components on the right-hand side of (4) indicates the share size of the contribution of each of productivity, employment rate, and share of labour force to any proportional change in output per capita. (4) shows that any change in output per capita is accounted for by changes attributed to productivity growth, employment rate, and the share of the labour force. This implies that the resulting size of a change in output per capita is linked to the size and direction of change in each of the marginal contributions. For instance, output per capita will rise in a given period as long as the (relatively constant) marginal contribution of the labour force is positive and large enough, even though the marginal contribution of productivity is negative and that of employment rate is constant. Thus, output change is decomposed into a structural factor (productivity change) and demographic characteristics of population. The place of both structural and demographic factors in output decomposition thus suggests that as the working age population increases (for instance), the effect of structural factors on output reduces.

There are different levels of decomposition that can be derived from the baseline identity in (2). However, we focus on the decompositions related to employment changes. Employment changes are decomposed into changes in employment by sectors in order to observe the pattern of influences of sectoral output changes on changes in the employment rate:

$$
\frac{E}{W}=\sum_{i=1}^{n} \frac{E^{i}}{W} \quad \text { or } \quad r=\sum_{i=1}^{n} r^{i}
$$

where $E^{i}$ is employment in sector $i$, and $r^{i}$ is employment rate in sector $i$. (6) therefore shows the role played by each sector on the direction of change of employment rate in the economy (World Bank, 2006).

Finally, output per worker (productivity) growth $(\Delta p)$ in sector $(v)$ between any two periods $t$ $=0$ and $t=1$, is decomposed as: 


$$
\begin{aligned}
\Delta p_{t}= & \underbrace{\Delta p_{1} *\left(\frac{v_{1, t=0}+v_{1, t=1}}{2}\right)+\Delta p_{2} *\left(\frac{v_{2, t=0}+v_{2, t=1}}{2}\right)+\cdots+\Delta p_{i} *\left(\frac{v_{i, t=0}+v_{i, t=1}}{2}\right)}_{\Delta p_{w}} \\
& +\underbrace{\sum_{i=1}^{v} \Delta v_{i} *\left(\frac{p_{i, t=0}+p_{i, t=1}}{2}\right)}_{\Delta p_{b}}
\end{aligned}
$$

From the decomposition in (7), $\Delta p_{i} *\left(\frac{v_{i, t=0}+v_{i, t=1}}{2}\right)$ represents the productivity change that is linked to changes in productivity in each sector $i$, which sum up to $\Delta p_{w}$ and corresponds to total changes in productivity less the reallocation effects of structural changes. These are the within-sector shifts in productivity, on the assumption that there are no shifts in employment shares within the same period. On the other hand, $\Delta p_{b}$ is the productivity change arising from shifts in employment between sectors (or between-sector productivity changes). If the last term is negative, there is indication that sectoral employment reallocation has led to decline in aggregate productivity growth in the economy.

Decomposition using the Shapely method is preferred because it not only decomposes sectoral productivity and employment, it is an economy-wide growth accounting framework that traces growth to all major aspects of economic structure as shown in Bbaale (2013). The method however suffers from the static nature of the analysis. This shortcoming of the decomposition analysis is however minimised given that a moving average base period is employed instead of a single base period. Moreover, the Shapely decomposition method provides a strong background for observing shift patterns within and between sectors in terms of productivity and employment rates (McMillan \& Rodrick, 2011; Fuchs \& Weyh, 2014).

\section{Results and Discussion}

The decomposition of employment based on structural and demographic factors is done in this section. The results are obtained from the JoGGs decomposition processes described in the previous section for the ten selected countries. Comparison of output, structural, and employment shifts among the two periods provide useful insights on employment outcomes of structural changes in the region. 
Decomposing Employment Growth in Selected sub-Saharan

African Countries: The Roles of Structural Changes and

Demographic Transition

Adegboye and Ighodaro

\subsection{Preliminary Investigation of Decomposition Data}

Summary description of the pattern of economic structure, demographics and employment for the countries in the study is essential for understanding the general status of the countries over the periods. The summary of the main indicators for the sampled countries is presented on Table 1, which shows percentage changes in the variables between the periods in the analysis. For per capita GDP value added, Botswana and Mauritius had remarkable increases over the 1970 to 2014 period. Considering that the GDP is in real terms, the phenomenal growth rate underscores the sustained and persistent growth that the two countries have enjoyed since the late 1970s. A combination of two factors could be responsible for this impressive growth: the initial condition of GDP per capita (especially for Botswana), and sectoral adjustments executed on the bases of stronger institutions (United Nations Conference on Trade and Development, [UNCTAD], 2001; Jayne et al, 2018). In the case of Botswana, McCaig et al. (2016) highlighted the swift transition of the country from being one of the poorest at independence in 1966 to becoming a middle-income country as early as 1986 and an upper-middle-income country in 2005. Mauritius currently has one of the highest GDP per capita in SSA, with high welfare indicators.

Table 1: Summary of Percentage Changes in Basic Data Series

\begin{tabular}{|c|c|c|c|c|c|c|c|c|}
\hline \multirow[t]{2}{*}{ Country } & \multicolumn{2}{|c|}{$\begin{array}{l}\text { GDP (v.a.) per } \\
\text { capita }(\%)\end{array}$} & \multicolumn{2}{|c|}{$\begin{array}{l}\text { Output per worker } \\
(\%)\end{array}$} & \multicolumn{2}{|c|}{$\begin{array}{l}\text { Employment rate } \\
(\%)\end{array}$} & \multicolumn{2}{|c|}{$\begin{array}{l}\text { Share of working- } \\
\text { age population }(\%)\end{array}$} \\
\hline & $\begin{array}{l}1970- \\
2014\end{array}$ & $\begin{array}{l}2000- \\
14\end{array}$ & $\begin{array}{l}1970- \\
2014\end{array}$ & $\begin{array}{l}2000- \\
14\end{array}$ & $\begin{array}{l}1970- \\
2014\end{array}$ & $\begin{array}{l}2000- \\
14\end{array}$ & $\begin{array}{l}1970- \\
2014\end{array}$ & $\begin{array}{l}2000- \\
14\end{array}$ \\
\hline Botswana & 333.4 & 9.9 & 286.6 & 12.6 & -11.7 & -6 & 13.5 & 2.3 \\
\hline Ethiopia & 46.2 & 43.2 & 42.3 & 39.6 & 3.1 & -0.2 & -0.2 & 1.4 \\
\hline Ghana & 42.4 & 21.7 & 38 & 15.4 & -7.4 & 3.7 & 5.9 & 1 \\
\hline Kenya & 1.6 & 6.6 & -8.5 & 6.2 & -4.4 & -0.8 & 7.6 & 0.7 \\
\hline Malawi & 16.3 & 21.7 & 17.5 & 20 & -0.2 & 0.8 & -0.4 & 0.3 \\
\hline Mauritius & 293.5 & 22.2 & 148.4 & 15.8 & 29.1 & 3.2 & 13.1 & 1.6 \\
\hline Nigeria & 6.5 & 16.3 & 33.2 & 9 & -19.3 & 7.2 & -0.5 & -0.2 \\
\hline Senegal & 2 & 6.4 & -20.2 & 5.1 & 25.1 & -0.1 & 1.1 & 0.7 \\
\hline $\begin{array}{l}\text { South } \\
\text { Africa }\end{array}$ & 18.8 & 10 & 33.4 & 13.9 & -23.7 & -5.7 & 9.2 & 1.4 \\
\hline Tanzania & 43.6 & 20.5 & 58 & 22.3 & -10.7 & -1.1 & 0.9 & -0.2 \\
\hline
\end{tabular}

Note: employment rate $=$ employment to working age population.

Source: Author's computations using JoGGs techniques

Output per worker, a measure of labour productivity, also had the largest positive change between 1970 and 2014 for Botswana and Mauritius with 286.6 percent and 148.4 percent respectively. Kenya and Senegal - which had the lowest changes in per capita GDP for the 
1970-2014 period - experienced negative productivity changes over the same period. Apparently, the poor economic performance in these countries could be largely traced to falling labour productivity over the period. The impressive changes in per capita GDP for the 20002014 period for all the countries were accompanied by rising aggregate labour productivity, with Ethiopia and Tanzania leading the rise in productivity for that period. Ethiopia gained productivity of 39.6 percent during the 2000-2014 period, suggesting that the country has had the most significant improvements in both output and productivity during the period. Similar findings were made in the study by Kabeta and Sidhu (2016).

The focus of this current study is on employment outcomes from sectoral adjustments (including shares and productivity), and demographic changes at any given time. The changes in employment rate over the sub-periods are therefore reported in the third panel of Table 1. It reveals generally poor changes in employment to working-age population ratio for most countries over the period. Only Mauritius exhibited positive changes in employment rate through the sub-periods, showing that employment rate grew by as much as 29.3 percent between 1970 and 2014, and 3.2 percent between 2000 and 2014. South Africa (-23.7 percent) and Nigeria (-19.1 percent) exhibited the largest decline in employment rate over the 1970-2014 period, while Mauritius and Senegal had the largest positive changes. Apparently, Mauritius was able to integrate employment growth in its impressive output growth over the period. Surprisingly, Botswana, which reported the highest per capita GDP changes between 1970 and 2014 had a 11.4 percent decline in employment rate during the same period. This is both surprising and disturbing since it indicates that per capita growth in GDP has not reflected in employment in the country. This further supports McCaig et al. (2016) finding that "Botswana's rapid economic growth has left many individuals behind", where unemployment, income inequality, and poverty have deepened with the rising output.

What could be responsible for the negative changes in employment rates in many of the countries between the periods? Explanation could be found in the pattern of changes in working-age population and economic structure. Since the employment rate incorporates the influences of demographic changes, a negative change in employment rate for a country reveals that the working-age population has grown faster than employment between the given periods. For countries that experienced sharp increases in the working-age population, the employment rate seemed to generally decline. Instances of rapid increases in the 
Decomposing Employment Growth in Selected sub-Saharan

African Countries: The Roles of Structural Changes and

Demographic Transition

Adegboye and Ighodaro

share of working-age population (demographic changes) were found in Botswana (13.5 percent - the highest among the countries) and South Africa (9.2 percent). Such changes may have accounted for the high negative changes in employment rate during the 1970-2014 period. In contrast, Nigeria had a negative change in working-age population for the period, while Mauritius (with the biggest positive change in employment rate) had a large increase in working-age population of 13.2 percent. Thus, demographic changes alone could not have accounted for the patterns of employment rate changes for the countries. Rather, the changes in economic structure that accompanied output growth over the period could have also contributed to the differences in the changes in employment rates among the countries - as also noted in Ajakaiye et al. (2016), for instance. The negative effects of a demographic transition which favours rising working-age population can be further observed in the scatterplot in Figures 1 and 2. The relationship between working age population and employment rates is negative for both 1970 and 2014, indicating that countries with a population structure with higher working age group tend to have lower rates of employment (employment per worker).

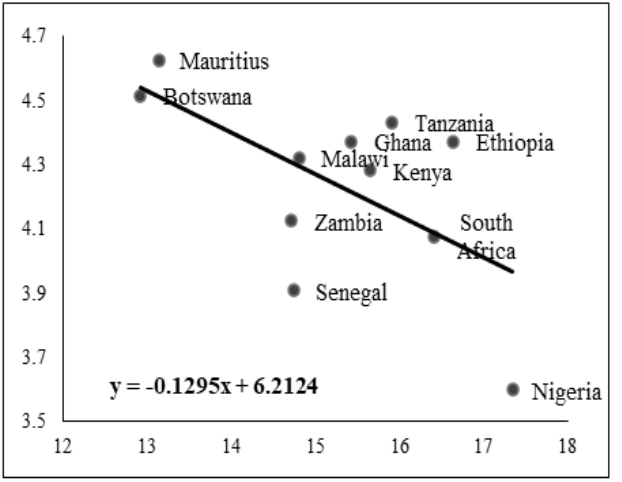

Figure 1: Working-age population and employment rate, 1970

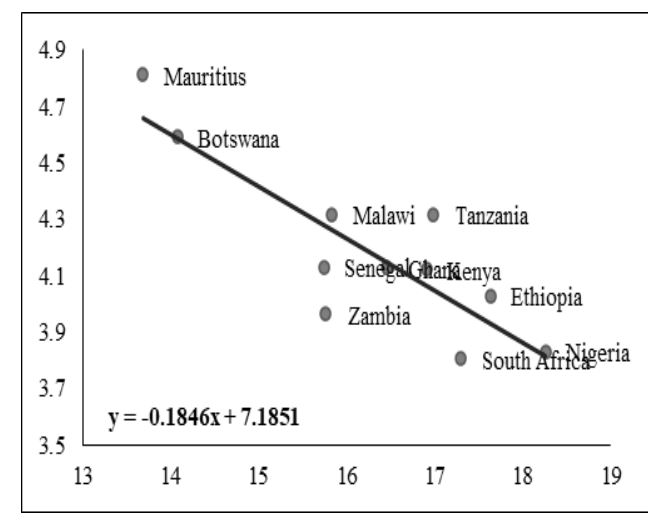

Figure 2: Working-age population and employment rate, 2014

Another point to consider is the comparative changes in per capita GDP or productivity and employment rate for the countries. One could be interested in assessing whether periods with larger shifts in GDP per capita coincided with periods with bigger changes in employment rates. On Table 1, only Botswana and, to a lesser extent, Kenya, Malawi and Nigeria matched per capita GDP changes with employment changes. This indicates that for most of the countries, not only were large positive GDP changes not accompanied by positive em- 
ployment changes, periods of large GDP changes coincided with periods of low (or negative) employment changes. This is also demonstrated in the negatively sloped regression lines in the relationship between output per capita and employment rate shown in Figures 3 and 4. These outcomes are in line with findings by Page and Shimeles (2015) and McMillan and Rodrik (2011) which suggest that structural changes that accompanied growth tended to limit employment outcomes in the region.

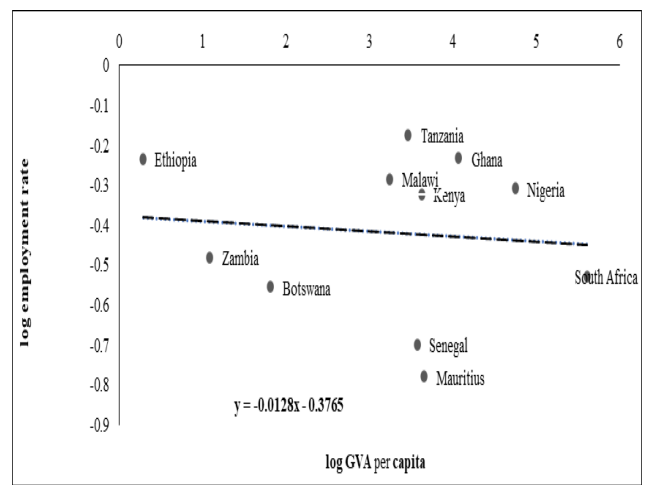

Figure 3: Output per capita and employment rate, 1970

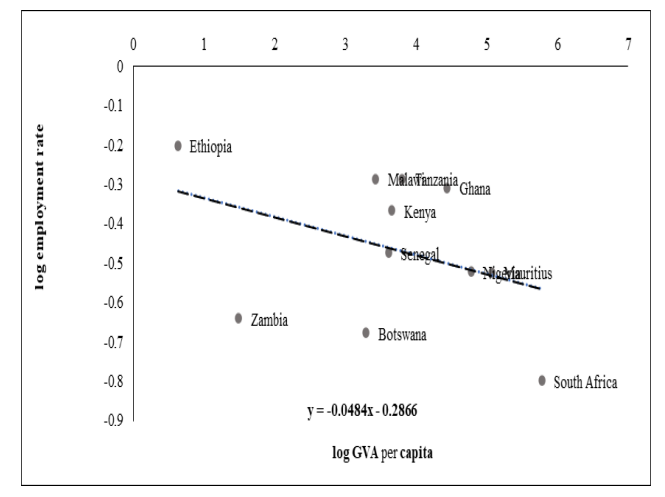

Figure 4: Output per capita and employment rate, 2014

\subsection{Decomposition of Employment and Output in SSA}

Understanding the roles of economic structure and demographic changes on employment growth among the selected countries involves assessing the pattern of changes in employment rate. The linkages with growth in output and sectoral variations, as well as how intersectoral shifts affect employment in these countries are also essential. These are the analyses performed in this sub-section. On Table $2 \mathrm{a}$ and $\mathrm{b}$, decomposition of changes in employment rates in relation to changes in the compositions of output and demographic factors are reported for the period 1970-2014 and 2000-2014 respectively. The sectors include agriculture, mining, utilities and construction, manufacturing, trade services, government services, and other services (including communication and tourism). The Tables show changes in employment rates in each country for the sectors. A significant reflection of the combined roles of sectoral output changes and demographic transition on employment is demonstrated in the proportion of the working population that is in employment at any given time (the employment rate). 
Decomposing Employment Growth in Selected sub-Saharan

African Countries: The Roles of Structural Changes and

Demographic Transition

Adegboye and Ighodaro

Table 2a: Changes in Employment Rate by Sectors of Economic Activity, 1970-2014

\begin{tabular}{|c|c|c|c|c|c|c|c|}
\hline Country & Agriculture & $\begin{array}{l}\text { Mining } \\
\text { and } \\
\text { Utilities }\end{array}$ & $\begin{array}{l}\text { Manufac- } \\
\text { turing }\end{array}$ & $\begin{array}{l}\text { Trade ser- } \\
\text { vices }\end{array}$ & $\begin{array}{l}\text { Government } \\
\text { Services }\end{array}$ & $\begin{array}{l}\text { Other } \\
\text { services }\end{array}$ & Total \\
\hline Botswana & -51.0 & -34.0 & 260.2 & 521.0 & 67.1 & -43.7 & -11.7 \\
\hline Ethiopia & -14.9 & 688.0 & 269.4 & 243.6 & 55.6 & 51.8 & 3.1 \\
\hline Ghana & -29.9 & 16.4 & -26.4 & 66.7 & -10.0 & 44.8 & -7.4 \\
\hline Kenya & -42.2 & 170.2 & 241.3 & 206.1 & 44.8 & 91.1 & -4.4 \\
\hline Malawi & -24.2 & 91.6 & 26.9 & 352.3 & 181.7 & 75.8 & -0.2 \\
\hline Mauritius & -67.3 & 1.8 & 40.3 & 267.1 & 121.0 & -0.2 & 29.1 \\
\hline Nigeria & -26.4 & 3.7 & -79.7 & 33.3 & 102.0 & 120.8 & -19.3 \\
\hline Senegal & -10.5 & 171.4 & 112.3 & 218.9 & 25.6 & 45.1 & 25.1 \\
\hline S.A. & -63.6 & -49.8 & -36.7 & 39.3 & 62.3 & -14.9 & -23.7 \\
\hline Tanzania & -26.6 & 149.5 & 39.3 & 189.0 & 150.7 & 38.9 & -10.7 \\
\hline
\end{tabular}

For each of the countries, the employment rate in the agricultural sector fell between the periods, suggesting that agriculture has lost a large share of employment since the 1970s. This is to be expected and has been generally reported in studies on structural transformation in the region (McMillan \& Harttgen, 2014; de Vries et al. , 2013; Gong, 2015). This negative change in employment rate in agriculture indicates movement of people out of agriculture to other sectors with higher productivity and hence, higher wages. In line with Lewis (1954) position, the migration of workers from agriculture to other sectors for more productive employment is a necessary requirement for inclusive growth. Mauritius (-67.3 percent), South Africa (-63.6 percent) and Botswana (-51.0 percent) lead in terms of decline of employment rate in the agricultural sector. Senegal and Ethiopia had the lowest change or decline over the period, indicating that these countries may still have large sections of the working population in the agricultural sector. Another explanation for the large declines in agricultural employment rates is the persistent fall in agricultural share in total GDP value added over the period (Martins, 2012; de Vries et al. , 2013; ACET, 2014). In particular, "by the early 2000s, the weight of agriculture in total GDP had declined to uncharacteristically low levels when compared to countries with similar income levels" (Martins, 2012). This trend has had profound negative impacts on the agricultural sector in the region in terms of employment and productivity.

A major question to be answered is where the large employment movement away from agriculture has entered within the period. As shown on Table 2a, the services sector (especially trade services) has received more employment share than any of the other sectors. Ethiopia 
experienced a huge positive change in employment rate in the mining and utilities sector of 688.0 percentage points. This indicates that a very large section of the working population in the country moved into the mining and utilities sector, which is basically a primary sector. Interestingly, only Ghana, Nigeria and South Africa (three of the biggest economies) had declines in manufacturing employment over the period. This suggests that the larger economies tend to have relocated labour away from manufacturing between 1970-2014. This is a plausible outcome given that in Nigeria, for instance, large labour-intensive manufacturing centers that thrived in the late 1960s and 1970s have disappeared significantly, leading to large job losses in the manufacturing sector (Chete et al. , 2015; Rodrik, 2016). For these countries, trade services accounted for the largest change in employment rates among the sectors.

The results from Table $2 \mathrm{a}$ also indicate that changes in economic structure in terms of employment has favoured the services sector over the period of 44 years under consideration. These are interesting outcomes because 44 years is a relatively short period for structural transition to transcend the standard pattern (Timmer et al. , 2015), namely, from traditional primary sector to secondary sector, and then to the tertiary sector. Rapid deindustrialisation of the SSA region during the intervening period between 1970 and the 2000s is conspicuously highlighted by these results. In this case, the industrial sector (especially manufacturing) has been left behind in the transformation process resulting in "premature deindustrialization" as indicated by Rodrik (2016). In their analysis of employment and structural changes in the SSA region, Rodrik et al. (2016) reaffirmed this outcome and noted that the process of structural change involving employment and output shares in SSA countries was not "following the standard patterns that we are familiar with from the historical literature or from widely used models of structural change".

For the changes in employment rates between 2000 and 2014, Table $2 \mathrm{~b}$ shows that the growth in proportions of employment was consistently negative for the agricultural sector for each of the countries. Within this period, Ethiopia, Malawi and Tanzania exhibited the largest gains in employment rate in the mining and utilities sector. Ethiopia, Malawi and Tanzania also had the strongest increases in employment rates for the manufacturing sector. Mauritius, South Africa, Nigeria and Botswana all had declines in employment rate in the manufacturing sector during the 2000-2014 period. Indeed, South Africa experienced declines in employment rates for each of the sectors during the period and had an overall decline of 1.1 percent. 
Decomposing Employment Growth in Selected sub-Saharan

African Countries: The Roles of Structural Changes and

Demographic Transition

Adegboye and Ighodaro

Once again, the trade services sector dominated in most of the countries in terms of increases in employment rate over the 2000-2014 period. Interestingly, the decomposition shows that long-term trends of structural characteristics of employment persisted even within the shorter term.

Table 2b: Changes in Employment Rate by Sectors of Economic Activity, 2000-2014

\begin{tabular}{llllllll}
\hline & $\begin{array}{l}\text { Agricul- } \\
\text { ture }\end{array}$ & $\begin{array}{l}\text { Mining } \\
\text { and Utili- } \\
\text { ties }\end{array}$ & $\begin{array}{l}\text { Manufac- } \\
\text { turing }\end{array}$ & $\begin{array}{l}\text { Trade } \\
\text { services }\end{array}$ & $\begin{array}{l}\text { Government } \\
\text { Services }\end{array}$ & $\begin{array}{l}\text { Other } \\
\text { services }\end{array}$ & Total \\
\hline Botswana & -4.7 & -50.6 & -1.6 & 25.4 & -16.2 & -20.0 & -6.0 \\
Ethiopia & -8.6 & 72.5 & 48.5 & 56.5 & 1.8 & -0.4 & -0.2 \\
Ghana & -10.9 & 4.8 & 1.1 & 23.8 & 21.0 & 25.8 & 3.7 \\
Kenya & -8.4 & 15.4 & 5.5 & 12.8 & -0.5 & 4.7 & -0.8 \\
Malawi & -13.4 & 59.2 & 39.0 & 48.9 & 28.7 & 61.2 & 0.8 \\
Mauritius & -18.5 & 4.3 & -16.7 & 22.3 & 6.8 & 9.8 & 3.2 \\
Nigeria & -7.3 & 33.8 & -4.2 & 50.8 & 23.9 & 46.7 & 7.2 \\
Senegal & -4.7 & 8.4 & 9.8 & 5.0 & 3.0 & 1.3 & -0.1 \\
S.A. & -11.8 & -1.3 & -15.9 & -3.0 & -2.2 & -1.9 & -5.7 \\
Tanzania & -8.0 & 41.5 & 24.9 & 25.3 & 25.2 & 8.8 & -1.1 \\
\hline Source: Aut & &
\end{tabular}

Source: Author's computations using JoGGs techniques.

The contribution of each sector to overall changes in employment rates (employment to total working-population ratios) demonstrates the relevance of each sector (and its evolution) to employment growth in the economy. Tables $3 \mathrm{a}$ and $\mathrm{b}$ present the decompositions for the period 1970-2014 and 2000-2014 respectively. In Table 3a, it is seen that the agricultural sector contributed negatively to changes in employment rates for each of the countries. This implies that labour supply into the agricultural sector declined over the period because there were, on average, migration out of the agricultural sector in each of the countries. The rate of decline in agricultural sector employment contribution to total employment rate appears to be similar across the countries, although Senegal has -3.7 percent while Kenya has -24.4 percent. The negative contribution of the agricultural sector could be a result of structural transition, or sheer neglect of the sector. This has made the sector unable to provide more employment opportunities in the labour market. 
Table 3a: Contribution of between-sector employment changes to total change in employment rate, 1970-2014

\begin{tabular}{|c|c|c|c|c|c|c|c|c|}
\hline & Country & $\begin{array}{l}\text { Agricul- } \\
\text { ture }\end{array}$ & $\begin{array}{l}\text { Mining } \\
\& \\
\text { Utilities }\end{array}$ & $\begin{array}{l}\text { Manufac- } \\
\text { turing }\end{array}$ & $\begin{array}{l}\text { Trade } \\
\text { services }\end{array}$ & $\begin{array}{l}\text { Govern- } \\
\text { ment } \\
\text { Ser- } \\
\text { vices }\end{array}$ & $\begin{array}{l}\text { Other } \\
\text { ser- } \\
\text { vices }\end{array}$ & Total \\
\hline \multirow{10}{*}{$\begin{array}{l}\text { Contribution } \\
\text { to } \\
\text { change } \\
\text { in } \\
\text { total } \\
\text { employment } \\
\text { rate } \\
\text { (percent } \\
\text { points) }\end{array}$} & Botswana & -20.4 & -1.3 & 2.4 & 11.4 & 3.5 & -2.4 & -6.7 \\
\hline & Ethiopia & -10.7 & 1.9 & 3.7 & 6.1 & 0.7 & 0.8 & 2.5 \\
\hline & Ghana & -13.0 & 0.5 & -2.8 & 7.8 & -0.5 & 2.2 & -5.9 \\
\hline & Kenya & -24.4 & 1.6 & 6.3 & 8.2 & 1.3 & 3.8 & -3.2 \\
\hline & Malawi & -15.6 & 1.8 & 0.7 & 8.0 & 3.5 & 1.5 & -0.2 \\
\hline & Mauritius & -8.7 & 0.1 & 3.3 & 13.4 & 5.4 & 0.0 & 13.3 \\
\hline & Nigeria & -12.5 & 0.0 & -9.3 & 3.1 & 1.3 & 3.1 & -14.2 \\
\hline & Senegal & -3.7 & 1.6 & 3.3 & 9.2 & 0.7 & 1.5 & 12.5 \\
\hline & S.A. & -11.8 & -4.5 & -3.1 & 4.0 & 2.7 & -1.3 & -14.0 \\
\hline & Tanzania & -20.0 & 1.5 & 0.6 & 5.5 & 2.8 & 0.7 & -9.0 \\
\hline \multirow{10}{*}{$\begin{array}{l}\text { Contribution } \\
\text { of the } \\
\text { sector } \\
\text { to } \\
\text { growth } \\
\text { in } \\
\text { employment } \\
(\%)\end{array}$} & Botswana & 304.4 & 18.9 & -36.2 & -170.3 & -52.2 & 35.5 & 100.0 \\
\hline & Ethiopia & -434.6 & 74.9 & 150.8 & 246.9 & 29.6 & 32.5 & 100.0 \\
\hline & Ghana & 221.5 & -8.0 & 48.4 & -133.1 & 9.2 & -38.0 & 100.0 \\
\hline & Kenya & 765.5 & -49.7 & -196.3 & -258.3 & -40.8 & -120.4 & 100.0 \\
\hline & Malawi & 9041.8 & -1035.2 & -408.1 & -4641.8 & -2015.1 & -841.7 & 100.0 \\
\hline & Mauritius & -65.5 & 0.9 & 24.4 & 100.3 & 40.1 & -0.1 & 100.0 \\
\hline & Nigeria & 88.1 & -0.3 & 65.6 & -21.9 & -9.4 & -22.1 & 100.0 \\
\hline & Senegal & -29.9 & 12.7 & 26.1 & 73.7 & 5.2 & 12.2 & 100.0 \\
\hline & S.A. & 84.5 & 31.8 & 22.1 & -28.4 & -19.1 & 9.1 & 100.0 \\
\hline & Tanzania & 222.7 & -16.6 & -6.3 & -60.8 & -31.2 & -7.8 & 100.0 \\
\hline
\end{tabular}

Source: Author's computations using JoGGs techniques.

Trade services sector had the most potent contribution to changes in the overall employment rate across the countries, suggesting that this sector has absorbed most of the labour leaving the agricultural sector in these countries. All contribution values were positive and very high for Mauritius (13.4 percent), Botswana (11.4 percent), and Senegal (9.2 percent). Only government services in Ghana had a negative contribution to change in the employment rate among all the services sector for each country. Surprisingly, the mining and utilities sector did not contribute to change in employment rate in Nigeria for the period, while manufacturing employment rate dropped by 9.3 percent. This underscores the decline in manufacturing in Nigeria: indeed, agriculture (-12.5 percent) and manufacturing contributed immensely to the negative change in employment rate in Nigeria for the 1970-2014 period. South Africa also experienced a decline in employment rate in both mining and manufacturing sectors. However, Kenya (6.3 percent) Ethiopia (3.4 percent), Mauritius (3.3 percent), and Senegal (3.3 percent) all recorded strong increases in manufacturing employment for the same period. 
Decomposing Employment Growth in Selected sub-Saharan

African Countries: The Roles of Structural Changes and

Demographic Transition

Adegboye and Ighodaro

Note that the period recorded declining manufacturing output growth for many high income and middle income economies (Rodrik, 2016). Overall, only Mauritius, Senegal and Ethiopia experienced positive changes in employment rate over the 1970-2014 period.

The proportion of contribution of each sector to employment rate changes are shown in the second panel of the Table 3a. A very strong outcome is the largely negative coefficients reported in the second panel which can be linked to increasing working age population. For most of the countries, agriculture was the largest contributor to employment changes, while mining and utilities provided the least contribution. For a sector as large and important as the mining sector in these African economies, the low contributions (and in some cases negative) to employment rate suggests fundamental challenges for employment creation in the sector. Moreover, given that the sector is the most productive for most of the countries, the inability to boost jobs in this sector implies that strong policy measures are required either to control economic structure or to direct employment. This was also shown in studies by Haile (2018) and Martins (2019).

Table 3b: Contribution of employment changes to overall change in employment rate, 2000-2014

\begin{tabular}{|c|c|c|c|c|c|c|c|c|}
\hline & Country & $\begin{array}{l}\text { Agri } \\
\text { culture }\end{array}$ & $\begin{array}{l}\text { Mining } \\
\& \text { Util- } \\
\text { ities }\end{array}$ & $\begin{array}{l}\text { Manu- } \\
\text { facturing }\end{array}$ & $\begin{array}{l}\text { Trade } \\
\text { services }\end{array}$ & $\begin{array}{l}\text { Govern- } \\
\text { ment } \\
\text { services }\end{array}$ & $\begin{array}{l}\text { Other } \\
\text { services }\end{array}$ & Total \\
\hline \multirow{10}{*}{$\begin{array}{l}\text { Contribution } \\
\text { to change } \\
\text { in total } \\
\text { employment } \\
\text { rate } \\
\text { (percent } \\
\text { points) }\end{array}$} & Botswana & -1.0 & -2.5 & -0.1 & 2.8 & -1.7 & -0.8 & -3.2 \\
\hline & Ethiopia & -5.8 & 0.9 & 1.7 & 3.1 & 0.0 & 0.0 & -0.1 \\
\hline & Ghana & -3.7 & 0.2 & 0.1 & 3.8 & 0.8 & 1.5 & 2.6 \\
\hline & Kenya & -3.1 & 0.3 & 0.5 & 1.4 & 0.0 & 0.4 & -0.5 \\
\hline & Malawi & -7.6 & 1.4 & 0.9 & 3.4 & 1.2 & 1.3 & 0.6 \\
\hline & Mauritius & -1.0 & 0.3 & -2.3 & 3.4 & 0.6 & 0.8 & 1.8 \\
\hline & Nigeria & -2.7 & 0.3 & -0.1 & 4.2 & 0.5 & 1.8 & 4.0 \\
\hline & Senegal & -1.6 & 0.2 & 0.6 & 0.6 & 0.1 & 0.1 & 0.0 \\
\hline & S.A. & -0.9 & -0.1 & -1.0 & -0.4 & -0.2 & -0.1 & -2.7 \\
\hline & Tanzania & -4.8 & 0.7 & 0.4 & 1.7 & 0.9 & 0.2 & -0.8 \\
\hline \multirow{10}{*}{$\begin{array}{l}\text { Contribution } \\
\text { of the } \\
\text { sector } \\
\text { to growth } \\
\text { in } \\
\text { employment } \\
(\%)\end{array}$} & Botswana & 29.7 & 78.0 & 1.7 & -85.6 & 52.5 & 23.7 & 100.0 \\
\hline & Ethiopia & 4768.9 & -730.5 & -1369.2 & -2547.9 & -29.6 & 8.3 & 100.0 \\
\hline & Ghana & -143.5 & 5.9 & 3.2 & 144.9 & 32.4 & 57.1 & 100.0 \\
\hline & Kenya & 565.0 & -61.8 & -85.0 & -254.9 & 3.7 & -66.9 & 100.0 \\
\hline & Malawi & -1235.7 & 226.8 & 152.4 & 551.4 & 196.3 & 208.9 & 100.0 \\
\hline & Mauritius & -53.1 & 14.9 & -124.9 & 185.0 & 34.2 & 43.9 & 100.0 \\
\hline & Nigeria & -68.7 & 7.6 & -2.6 & 105.2 & 12.7 & 45.8 & 100.0 \\
\hline & Senegal & 4196.4 & -522.1 & -1462.8 & -1694.8 & -253.9 & -162.7 & 100.0 \\
\hline & S.A. & 33.6 & 2.2 & 37.4 & 16.0 & 5.7 & 5.1 & 100.0 \\
\hline & Tanzania & 583.8 & -89.3 & -48.8 & -206.1 & -114.9 & -24.7 & 100.0 \\
\hline
\end{tabular}

Source: Author's computations using JoGGs techniques. 
The sectoral contributions to employment rate changes between 2000 and 2014 is reported on Table 3b. For this period also, agriculture contributed negatively to employment rate changes, although the size of the contribution was not the biggest for most of the countries (contrary to the period between 1970-2014). This indicates that agricultural employment might have been stabilizing in the past few years. There were large swings in agricultural employment rate contribution in Ethiopia, Malawi, Tanzania and Ghana where it appears that strong structural movements away from the agricultural sector are still rampant. In Botswana and Mauritius, the contribution of the agricultural sector was low compared to mining, manufacturing, and trade services. There were strong drops in the employment rate in mining and government services in Botswana which resulted in the negative total employment change for the period. Positive changes in employment rates in trade services and other services (including ICT and finance) boosted overall employment rate change within the period in Nigeria, Mauritius, Ghana and Malawi. Only Ethiopia had a relatively strong positive change in manufacturing employment during the period, thus suggesting the neglect of the sector even during the economic boom period in the region. From the results, it is seen that employment rate growth during the 2000-2014 period was driven mainly by trade and other services in the SSA region.

Productivity changes are an essential aspect of structural transformation since productivity accounts largely for both the level and rate at which a growing sector (in terms of employment share) could contribute to overall GDP value added. In Tables $4 \mathrm{a}$ and $\mathrm{b}$, the percentage changes in productivity in each sector over the periods are reported. For most of the countries, during the 1970-2014 period, productivity gains were positive in the agricultural sector more than in any other sector, only Ethiopia and Senegal experienced negative productivity growth changes. The impressive productivity changes are not unrelated with the very low productivity in the sector in the early years, which have improved as more modernization were introduced in the sector, or as more labour moved away from the sector (see Ranis \& Fei, 1961).

Government and other services had very large productivity gains for some of the countries. Note that other services include financial, ICT and tourism services where productivity has been quite impressive over the past decade as a result of massive investment by both public and private sectors (Martins, 2019). For instance, productivity growth increased by 1131.9 percentage points between 1970 and 2014 in Botswana, 308 percentage points for Mauritius, 
Decomposing Employment Growth in Selected sub-Saharan

African Countries: The Roles of Structural Changes and

Demographic Transition

Adegboye and Ighodaro

and 120 points for Ethiopia. Positive changes in other services were also high in Nigeria and South Africa. This implies that for the larger and rapidly growing economies, ICT and finance services had very strong productivity growth over the 44 years period. Positive changes in manufacturing productivity growth occurred only in Nigeria (845.4 percent), Mauritius (161.9 percent) and South Africa (40.1 percent).

Table 4a: Percentage Changes in Output per Worker by Sectors, 1970-2014

\begin{tabular}{|c|c|c|c|c|c|c|c|}
\hline & Agricultur & $\begin{array}{l}\text { Mining } \\
\text { and } \\
\text { Utilities }\end{array}$ & Manufacturing & $\begin{array}{l}\text { Trade } \\
\text { services }\end{array}$ & $\begin{array}{l}\text { Government } \\
\text { Services }\end{array}$ & $\begin{array}{l}\text { Other } \\
\text { services }\end{array}$ & Total \\
\hline Botswana & 30.2 & 277.9 & -14.2 & -21.9 & 153.8 & 1131.9 & 286.6 \\
\hline Ethiopia & -4.4 & -74.3 & -44.6 & -23.9 & 300.3 & 120.0 & 42.3 \\
\hline Ghana & 51.9 & -1.9 & -9.0 & -1.4 & 109.3 & 33.4 & 38.0 \\
\hline Kenya & 5.6 & -75.1 & -65.4 & -59.5 & -36.7 & -50.3 & -8.5 \\
\hline Malawi & 61.7 & -15.4 & -3.0 & -74.7 & -71.5 & -34.3 & 17.5 \\
\hline Mauritius & 195.6 & 201.2 & 161.9 & 3.5 & 36.3 & 308.0 & 148.4 \\
\hline Nigeria & 65.6 & -46.1 & 845.4 & 118.2 & -6.9 & 86.6 & 33.2 \\
\hline Senegal & -25.8 & -35.3 & -54.1 & -66.1 & -35.9 & -5.4 & -20.2 \\
\hline S.A. & 114.2 & 5.9 & 40.1 & -4.4 & -42.6 & 66.5 & 33.4 \\
\hline Tanzania & 66.5 & -27.4 & -19.7 & -47.6 & -42.5 & 9.9 & 58.0 \\
\hline
\end{tabular}

Source: Author's computations using JoGGs techniques.

For Nigeria in particular - which had the largest productivity gains in the manufacturing sector, the concomitant low employment gains in the sector is a rather inauspicious outcome of the structural transformation process. Trade services (which incidentally had the largest gains in employment rate) had the largest productivity losses among the countries. Thus, the sector with the least contribution to productivity improvement has the highest contribution to employment rate. This invariably will result in considerable weakening of the ability of the sectors to sustain output growth in the long run (McMillan \& Rodrik, 2011; Osei \& Jedwab, 2016). The weak productivity gains may however signal a side effect of strong labour market performance in the trade services sector (de Michelis et al. , 2013). 
Table 4b: Percentage Changes in Output per Worker by Sectors, 2000-2014

\begin{tabular}{llllllll}
\hline & $\begin{array}{l}\text { Agri- } \\
\text { culture }\end{array}$ & $\begin{array}{l}\text { Mining } \\
\text { and } \\
\text { Utilities }\end{array}$ & $\begin{array}{l}\text { Manufac- } \\
\text { turing }\end{array}$ & $\begin{array}{l}\text { Trade } \\
\text { services }\end{array}$ & $\begin{array}{l}\text { Government } \\
\text { Services }\end{array}$ & $\begin{array}{l}\text { Other } \\
\text { services }\end{array}$ & $\begin{array}{l}\text { Total em- } \\
\text { ployment } \\
\text { rate }\end{array}$ \\
\hline Botswana & 33.46 & 46.45 & 25.41 & 6.01 & 20.02 & 73.42 & 12.55 \\
Ethiopia & 35.76 & -19.77 & -10.77 & 2.31 & 42.43 & 51.24 & 39.55 \\
Ghana & 23.84 & 37.77 & 0.41 & -1.89 & 4.24 & -1.13 & 15.37 \\
Kenya & 2.77 & 0.62 & 0.69 & 0.53 & -2.54 & 8.35 & 6.16 \\
Malawi & 21.6 & -1.16 & -6.18 & -14.35 & -26.03 & -17.54 & 19.96 \\
Mauritius & 23.76 & 17.54 & 26.73 & -1.21 & 9.06 & 24.76 & 15.84 \\
Nigeria & 29.77 & -31.88 & 39.62 & 1.61 & -4.39 & -9.36 & 8.95 \\
Senegal & 14.59 & 0.74 & -10.8 & -6.09 & -0.5 & 17.33 & 5.1 \\
S.A. & 15.91 & 1.85 & 18.86 & 17.13 & 10.14 & 10.34 & 13.94 \\
Tanzania & 14.58 & -6.11 & 4.5 & -0.37 & -2.29 & 18.24 & 22.26 \\
\hline \multicolumn{7}{l}{ Source: Author's computations using JoGGs techniques. } \\
\end{tabular}

For the 2000-2014 period, the results on Table $4 \mathrm{~b}$ show that all the countries experienced overall positive productivity changes, with Ethiopia at 39.55 percent and Tanzania at 22.26 percent leading the pack. Agricultural sector had positive productivity gains in all the countries, which underscores the assertion that the agricultural sector may have attained a reasonable level of stability across the region. Malawi had negative productivity gains in all the sectors except agriculture, while Mauritius had productivity loss in trade services alone. Botswana had positive productivity changes in all the sectors through the period, with largest gains occurring in other services, mining and utilities, and agriculture. In manufacturing, Nigeria again had the largest positive productivity changes, while Botswana and Mauritius also performed well. The largest single productivity loss over the 2000-2014 period is in Nigeria for the mining and utilities sector. Perhaps, the inclusion of utilities in the sector (including power) affected productivity significantly. Adeyinka et al. (2016) highlighted the power sector as a major source of low productivity in Nigeria where "self-generation" has required "substantial resources that could otherwise be used to invest in the firms' productivity or for expansion and the creation of new wage positions". 
Decomposing Employment Growth in Selected sub-Saharan

African Countries: The Roles of Structural Changes and

Demographic Transition

Adegboye and Ighodaro

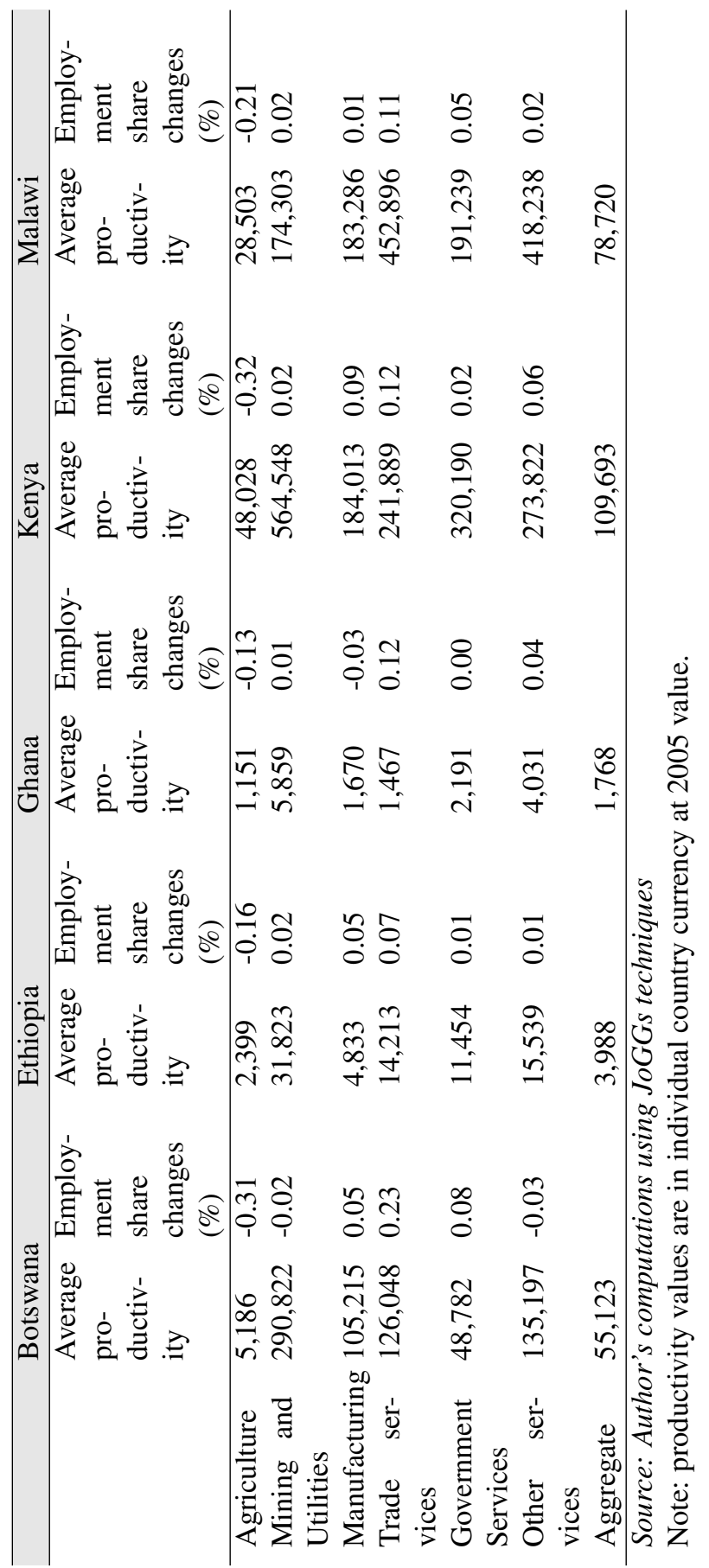




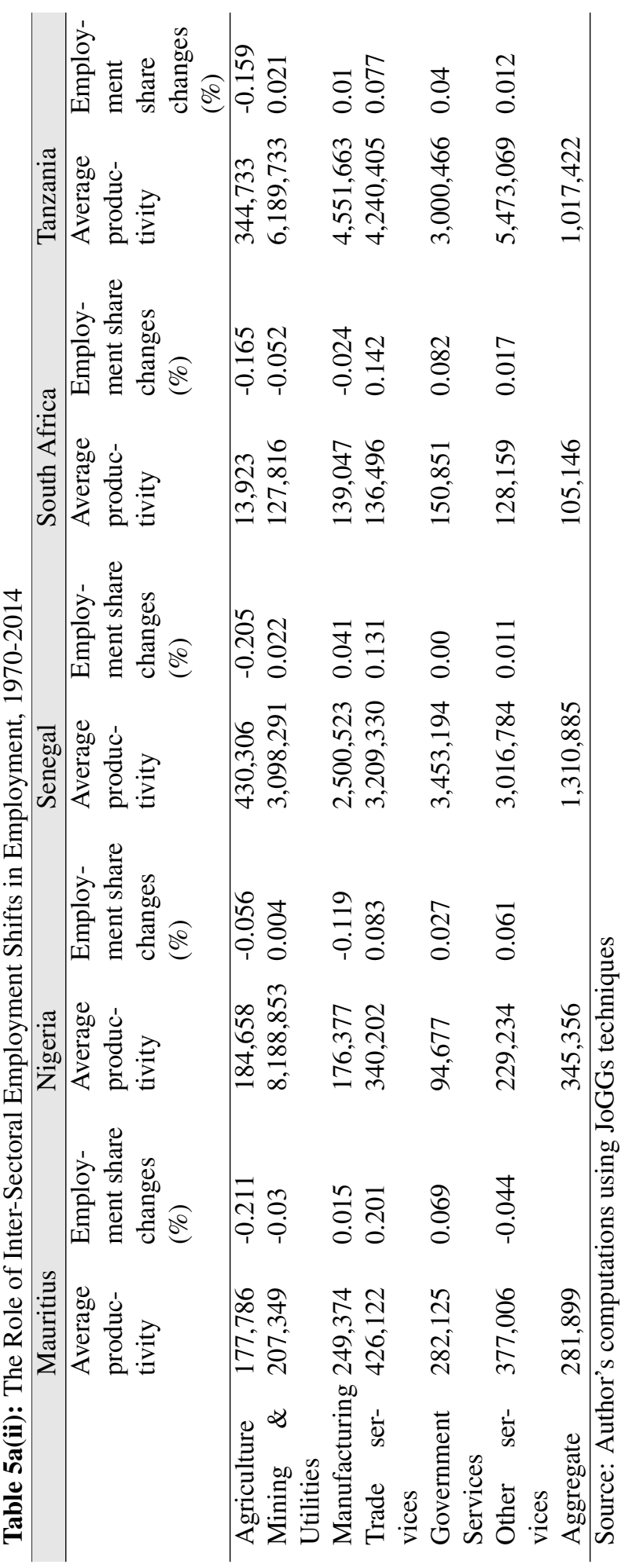


Decomposing Employment Growth in Selected sub-Saharan

African Countries: The Roles of Structural Changes and

Demographic Transition

Adegboye and Ighodaro

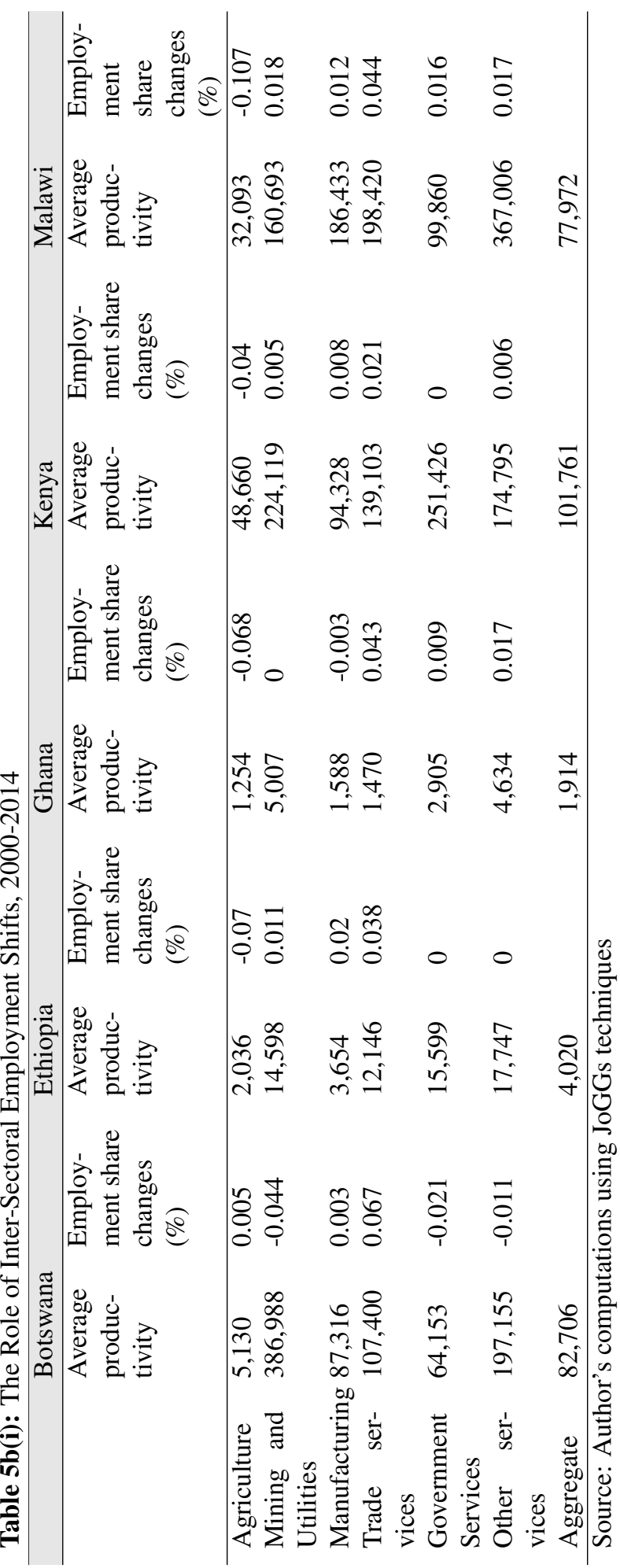




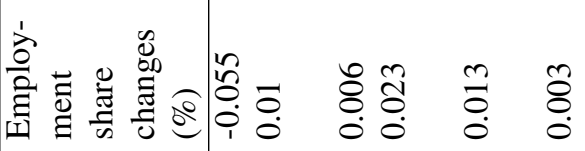

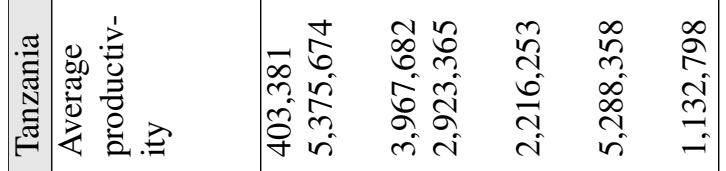

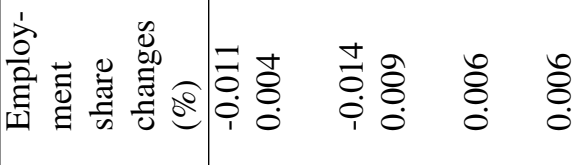

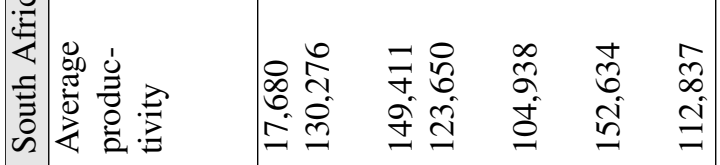

穿焉

至营兽

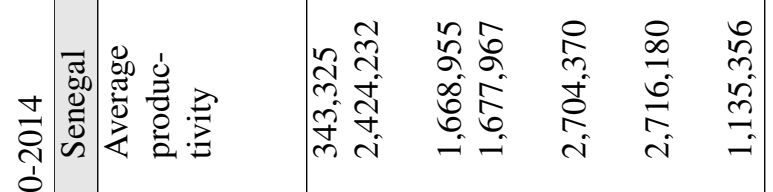

¿ุ

ते

㐘

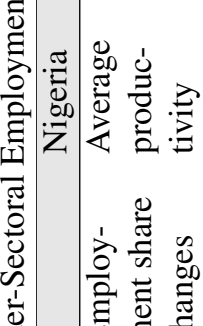

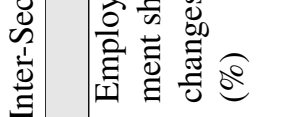

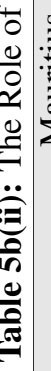

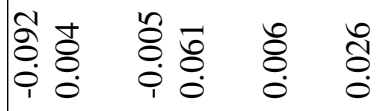

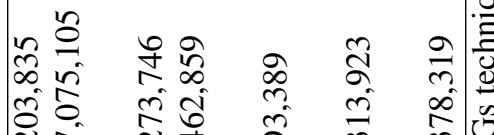

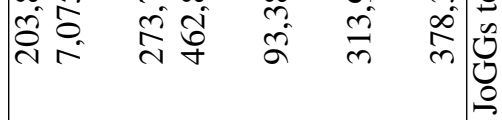

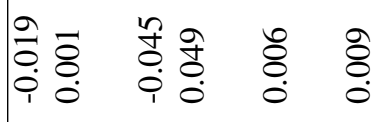

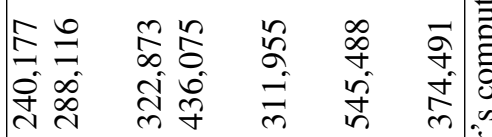

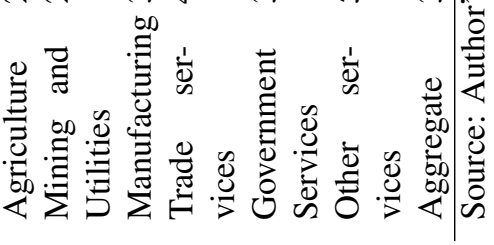


Decomposing Employment Growth in Selected sub-Saharan

African Countries: The Roles of Structural Changes and

Demographic Transition

Adegboye and Ighodaro

The next set of analysis involves the inter-sectoral employment shifts resulting from structural reallocation of the labour factor. On Tables $5 \mathrm{a}$ and $\mathrm{b}$, these results are reported including the average productivity in each of the sectors for the sub-periods under consideration. For all the countries, average productivity was lowest in the agricultural sector - as expected in both theoretical and empirical postulations (e.g., Lewis 1954; Diao, 2017). On the other hand, average productivity was highest in mining and utilities for many of the countries, including Botswana, Ethiopia, Ghana, Kenya, Nigeria and Tanzania. Average productivity was highest in trade services for Malawi and Mauritius, while government services had the highest productivity in Senegal and South Africa, although other sectors had similar productivity averages over the period too.

In terms of changes in employment shares, agriculture again was negative for all the countries, and Botswana (with 0.31 percentage points) experienced the biggest change. These are very large shifts of labour outside the agricultural sector. When changes in employment shares for the other sectors are considered, it is seen that for each country, no (positive) sectoral share changes matched that of (negative) agriculture sector changes. This indicates that no sector in the economies was absorbing labour as rapidly as the agricultural sector was discharging labour. Apparently, this pattern portends risks of unemployment in these economies and constitutes part of the employment problem highlighted by Fields (2011).

Employment share in trade services had the largest inward labour reallocation in the countries. But, this sector led in productivity values for only two of the ten countries. Thus, labour has not moved into the most productive sectors in many of the SSA countries. For the mining and utilities sector, changes in employment share for the period were between -0.05 and 0.02 percentage points, compared to between 0.07 and 0.23 percentage points in the mining sector. Changes in manufacturing employment shares were negative for Nigeria, Ghana and South Africa. However, the job gains in high-end services (e.g. ICT) reflects a successful shift of labour in some countries. For instance, AfDB (2012) observed that Mauritius expanded its tertiary sector through highly productive and labour intensive activities. This is a clear-cut lesson to be learnt by other countries in terms of a pattern of investment that could nudge the labour market into more productive services.

For the 2000-2014 period, the results on Table 5b indicate that agricultural productivity improved relative to the other sectors for most of the economies and employment share of the 
sector increased in Botswana by 0.005 percentage points. It thus appears that evolution of the economies tends to improve productivity in traditional sectors as also demonstrated in Ranis and Fei (1961). For the other countries, however, the share of agricultural employment declined between 2000 and 2014. Once, again, the biggest changes in employment shares were in the trade services sector, even though the sector did not have the biggest average productivity for each of the countries. Change in employment share of government services has remained impressive for many of the countries, though there has been a general decline. Apparently, the celebrated reduction of government size in some SSA countries has not effectively reduced employment, nor productivity in the sector for most of the countries. There is indication that the employment shares of the government sector also increased, as economic growth led to higher budgets in many of the countries (Osei \& Jedwab, 2016). In Nigeria, productivity in the government sector is remarkably low suggesting that the sector has a large employment level of low quality labour, resulting in wastages in many cases.

\section{Conclusion and Policy Recommendations}

For a long time, economists considered employment generation as only a by-product of long run growth or patterns of structural adjustments. This has led to growth-focused policies that have struggled to create widespread good jobs. These features have changed, especially for developing economies where pro-poor or inclusive growth has been the focus since the turn of the century. Today, employment is increasingly a top priority for many developing countries since it is considered as being capable of delivering poverty-reduction effects. This study set out to establish the basic channels through which employment growth have been achieved over time for a set of SSA countries. The channels considered include structural changes and demographic conditions. Decomposition analysis used the Jobs Generation and Growth (JoGGs) method which generates results akin to the McMillan-Rodrik system. In this approach, employment, output and sectoral productivity shares were decomposed between pairs of periods (years) in a system where the roles of economic structure and demographic changes could be observed.

A broad highlight from the study indicated that though structural change is a potential component for employment characteristics in the selected SSA economies, demographic transitions could also provide strong background for analyzing how employment changed over time. Major consequences of the nature of demographic changes in the SSA region have 
Decomposing Employment Growth in Selected sub-Saharan

African Countries: The Roles of Structural Changes and

Demographic Transition

Adegboye and Ighodaro

been shown to include large informalities in employment structure (large traditional sector employment) and increasing low-productivity jobs. Transition of the economy to the services sector has also been shown to be a fundamental condition for employment generation in the region. When considered broadly, the study shows that employment ensues from overall increases in sectoral shares at any given period in the region. This overall position however includes certain caveats especially when structural implications are considered. For instance, the results suggest that the dynamics of growth in relation to economic structure in SSA is rather precarious. This is because the growing sector, and one towards which the economies appear to be transiting into (services sector), does not appear to possess the capacity of generating the much-needed productive employment over time for many economies in the SSA region. In the same vein, the structure of economies in SSA has been shown to have a unique character in terms of employment outcomes in its adjustments. It was demonstrated that more employment has flowed onto the less productive segments of the services sector (i.e., traditional services).

The structure of SSA economies therefore need to be influenced with policies that can help to direct capital investment into services that are capable of boosting productivity (such as ICT and tourism). These sectors are labour intensive and can sustainably generate productive employment over time. Moreover, economies in SSA should find ways of adjusting into labour intensive aspects of global value chains. This will not only ensure meaningful engagement of the labour force but will improve on skills and overall productivity of labour. Finally, results from the study imply that policies that do not take the structure of population in SSA countries into account may not effectively measure the true employment position in the region. Moreover, demographic influences tend to magnify employment dilemmas by weakening employment rates and watering down productivity of labour in the SSA region. Given that the region has the highest rate of new entrants into the labour market (ILO, 2020), policies need to be used to address the demographic changes in the SSA region. Policies to curb excessive births and especially movements into urban centers are required to ensure that demographic factors do not further inhibit productive employment availability in the region.

\section{References}

Acemoglu, D., Johnson, S., \& Robinson, J. A. (2005). Institutions as the fundamental cause of long-run growth. Handbook of Economic Growth, 1A, 386-472. 
Adegboye, A. C., Egharevba M.I., \& Edafe J. (2019). Economic regulation and employment intensity of output growth in sub-Saharan Africa. In A. Elhiraika, G. Ibrahim G, \& W. Davis (Eds.), Governance for structural transformation in Africa (pp. 101-143). Palgrave Macmillan.

Adeyinka, A., Salau, S., \& Vollrath, D. (2016). Structural change and the possibilities for future growth in Nigeria. In M. McMillan, D. Rodrik, \& C. Sepúlveda (Eds.), Structural change, fundamentals, and growth: A framework and case studies (pp. 197-234). International Food Policy Research Institute.

African Center for Economic Transformation (2014). 2014 African transformation report: Growth with depth. Accra, Ghana.

African Development Bank (AfDB) (2012). African economic outlook, 2012: Promoting youth employment. African Development Bank.

Aggarwal, A. (2018). Economic growth, structural change and productive employment linkages in India: Did market transition matter? South Asia Economic Journal, 19(1), 64-85. https://doi.org/10.1177/1391561418761074

Ajakaiye, O., Jerome, A. T., Nabena, D. \& Alaba, O. A. (2016). Understanding the relationship between growth and employment in Nigeria. In H. Bhorat, \& F. Tarp (Eds.), Africa's lions: Growth traps and opportunities for six African economies (pp. 181228). Brookings Institution Press.

Bbaale, E. (2013). Is Uganda's growth profile jobless? International Journal of Economics and Finance, 5(11), 105-123.

Bhorat, H., Naidoo, K., Oosthuizen, M., \& Pillay, K. (2016). Demographic, employment and age trends in South Africa. In H. Bhorat, \& F. Tarp (Eds.), Africa's lions: Growth traps and opportunities for six African economies (pp. 181-228). Brookings Institution Press.

Boulhol, H. (2009). The effects of population structure on employment and productivity. OECD Economics Department Working Papers No. 684.

Broadberry, S. N. \& Crafts, N.F.R. (2003). UK productivity performance from 1950 to 1979: A restatement of the Broadberry-Crafts view. The Economic History Review, 56(4),718-735.

Campbell, D. (2013). The labour market in developing countries. In S. Cazes \& S. Verick (Eds.) Perspectives on labour economics for development (pp.7-38). International Labour Organization.

Carmignani, F., \& Mandeville, T. (2014). Never been industrialized: A tale of African structural change. Structural Change and Economic Dynamics, 31, 124-137. https://doi.org/10.1016/j.strueco.2014.09.002 
Decomposing Employment Growth in Selected sub-Saharan

African Countries: The Roles of Structural Changes and

Demographic Transition

Adegboye and Ighodaro

Chete, L. N., Adeoti, J. O., Adeyinka, F. M., \& Ogundele, O. (2015). Industrial development and growth in Nigeria: Lessons and challenges. Brookings Institute Learning to Compete Working Paper No. 8.

Coulibaly, B. S., Gandhi, D. \& Mbaye, A. A. (2019). Job creation for youth in Africa: Assessing the potential of industries without smokestacks. Brookings Institute AGI Working Paper No.22.

de Michelis, A., Estevão, M., \& Wilson, B.A. (2013). Productivity or employment: Is it a choice? International Productivity Monitor, 25(Spring), 41-60.

de Vries, G. J., Timmer, M.P., \& de Vries, K. (2013). Structural transformation in Africa: Static gains, dynamic losses. Journal of Development Studies, 51(6), 674-688. https://doi.org/10.1080/00220388.2014.997222

Diao, X., Harttgen, K., \& McMillan, M. (2017). The changing structure of Africa's economies. National Bureau of Economic Research (NBER) Working Paper No. 23021 January. https://www.nber.org/papers/w23021 Assessed on 03/07/2017.

Fields, G. S. (1975). Rural-urban migration, urban unemployment and under-development, and job-search security in LDCs. Journal of Development Economics, 2(2), 165-87.

Fields, G. S. (2011). Labor market analysis for developing countries. Labour Economics, 18(1), S16-S22.

Fox, L., Senbet, L. W., \& Simbanegavi, W. (2016). Youth employment in sub-Saharan Africa: Challenges, constraints and opportunities. Journal of African Economies, 25(s1), i3-i15. doi.org/10.1093/jae/ejv027

Fuchs, M., \& Weyh, A. (2014). Demography and unemployment in East Germany: How close are the ties? IAB-Discussion Paper No. 26/2014.

Gong, X. (2015). African economic structural transformation: A diagnostic analysis. Journal of African Transformation, 1(1), 1-22.

Haile, F. (2018). Structural change in West Africa: A tale of gain and loss. World Bank Policy Research Working Paper No. 8336.

Haraguchi, N., Martorano, B., Sanfilippo, M., \& Shingal, A. (2019). Manufacturing growth accelerations in developing countries. Review of Development Economics, 23(4), 1696-1724. https://doi.org/10.1111/rode.12621

Harris, J., \& Todaro, M. (1970). Migration, unemployment, and development: A two sector analysis. The American Economic Review, 40, 126-142.

Havlik, P. (2015). Patterns of structural change in the new EU member States. DANUBE: Law and Economics Review, 6(3), 133-157. DOI: 10.1515/danb-2015-0009 
Herrendorf, B., Rogerson, R., \& Valentini, A. (2014). Growth and structural transformation. Handbook of Economic Growth, 2, 855-941. https://doi.org/10.1016/B978-0444-53540-5.00006-9

International Labour Office (ILO) (2013). Employment and social protection in the new demographic context. Report presented at the International Labour Conference, 102nd Session, International Labour Office, Geneva.

International Labour Office (2020). Global employment trends for youth 2020: Technology and the future of jobs. Geneva: ILO.

Jayne, T. S., Chamberlain, J., \& Benfica, R. (2018). Africa's unfolding economic transformation. The Journal of Development Studies, 54(5), 777-787.

Kabeta, Z. E. \& Sidhu, I. S. (2016). Service sector: The source of output and employment growth in Ethiopia. Academic Journal of Economic Studies, 2(4), 139-156.

Khan, A. R. (2011). Employment in Sub-Saharan Africa. Lessons to be learnt from East Asian experience. Africa Task Force Meeting, Initiative for Policy Dialogue, Addis Ababa.

Kuusk, A., Staehr, K. \& Varblane, U. (2015). Sectoral change and labour productivity growth during boom, bust and recovery in central and Eastern Europe. Eesti Pank The Working Paper Series. http://www.eestipank.ee/en/publications/series/workingpapers.

Lam, D. \& Leibbrandt, M. (2014). Youth bulges and youth unemployment. Paper prepared for the Population Association of America Annual Meeting Boston MA, May 1-3.

Lewis, W. A. (1954). Economic development with unlimited supply of labour. The Manchester School, 22, 139-191.

Martinez-Fernandez, C., \& Weyman, T. (2012). Demographic change and local development: Shrinkage, regeneration and social dynamics. OECD Publishing. https://doi.org/10.1787/9789264180468-en.

Martins, P. (2012). Growth, employment and poverty in Africa: Tales of lions and cheetahs. Background paper prepared for the World Development Report 2013.

Martins, P. M. G. (2019). Structural change rediscovered: The role of human and physical capital. World Bank Research \& Policy Briefs No. 24.

McCaig, B., McMillan, M., Verduzco-Gallo, V., \& Jefferis, K. (2016). Stuck in the middle? Structural change and productivity growth in Botswana. In M. McMillan, D. Rodrik, \& C. Sepúlveda (Eds.), Structural change, fundamentals, and growth: A framework and case studies (pp. 125-160). International Food Policy Research Institute. 
Decomposing Employment Growth in Selected sub-Saharan

African Countries: The Roles of Structural Changes and

Demographic Transition

Adegboye and Ighodaro

McMillan, M. S. \& Rodrik, D. (2011). Globalization, structural change, and productivity growth. In M. Bachetta, \& M. Jansen (Eds.), Making globalization socially sustainable (pp. 36-70). International Labour Organization and World Trade Organization.

McMillan, M. S. \& Harttgen, K. (2014). The changing structure of Africa's economies. Paper prepared as background paper for the African Economic Outlook 2015.

Newhouse, D. L. (2020). How does population growth affect African jobs? https://www.weforum.org/agenda/2015/12/how-does-population-growth-affect-africanjobs/.

Newhouse, D. L., \& Wolff, C. (2014). Cohort size and youth employment outcomes. World Bank Policy Research Working Paper No. 6848.

Osei, R. D. \& Jedwab, R. (2016). Structural change in a poor African country: New historical evidence from Ghana. In M. McMillan, D. Rodrik, \& C. Sepúlveda (Eds.), Structural change, fundamentals, and growth: A framework and case studies (pp. 161-196). International Food Policy Research Institute

Page, J., \& Shimeles, A. (2015). Aid, employment, and poverty reduction in Africa. African Development Review, 7(S1), 17-30. https://doi.org/10.1111/1467-8268.12136.

Ranis, S., \& Fei, J. C. (1961). A theory of economic development. The American Economic Review, 51, 533-558.

Rifkin, J. (1994). The end of work. New York City: Tarcher/Putman.

Rodrik, D. (2016). Premature deindustrialization. Journal of Economic Growth, 21(1), $1-33$.

Rodrik, D. McMillan, M. \& Sepúlveda, C. (2016). Structural change, fundamentals, and growth. In M. McMillan, D. Rodrik, \& C. Sepúlveda (Eds.), Structural change, fundamentals, and growth: A framework and case studies (pp. 1-38). International Food Policy Research Institute

Timmer, M. P. \& de Vries, G. J. (2008). Structural change and growth accelerations in Asia and Latin America: a new sectoral data set. Cliometrica, 3(2), 165 - 190. DOI: 10.1007/s11698-008-0029-5.

Timmer, M. P., de Vries, G. J., \& de Vries, K. (2015). Patterns of structural change in developing countries. In J. Weiss, \& M. Tribe (Eds.), Routledge Handbook of Industry and Development (pp. 65-83). Routledge.

Todaro, M. P., \& Smith, S. C. (2009). Economics development, (5th edition). Longman Group. 
United Nations Conference on Trade and Development (UNCTAD) (2001). Economic development in Africa: Performance, prospects and policy issues. Washington D.C.: The United Nations.

World Bank. (2006). Job generation and growth decomposition tool: Understanding the sectoral pattern of growth and its employment and productivity intensity. Available at: http://siteresources.worldbank.org/INTEMPSHAGRO/Resources/JoGGs_Decomposition _Tool_UsersGuide. Accessed 23/06/2015

World Bank (2012). World development report 2013: Jobs. Washington. World Bank. 